\title{
“Family Achievements?": How a College Degree Accumulates Wealth for Whites and Not For Blacks
}

\author{
Tatjana Meschede, Joanna Taylor, Alexis Mann, and Thomas Shapiro
}

\begin{abstract}
A college education has been linked to higher life-time earnings and better economic achievements, so the expectation would be that it is also linked to higher net wealth for everybody. However, recent analyses challenge this hypothesis and find that the expectation holds true for White college-educated households but not for Black college-educated households. To examine this finding further and investigate the role of family financial transfers in household net wealth, the authors perform a mixed-method study using data from the Panel Study of Income Dynamics for a 24-year period, 1989-2013, and qualitative data from the Institute on Assets and Social Policy Levering Mobility study. Their results confirm that White college-educated households amass wealth, whereas the wealth of their Black counterparts declines. The authors also estimate the impact of just inheritance or large financial gifts and find that they decrease the existing racial wealth gap by nearly $\$ 40,000$, or 20 percent.
\end{abstract}

Further analyses demonstrate that White college graduates are significantly and substantially more likely to provide and receive financial support for education and/or a home purchase, while Black college graduates are significantly more likely to financially support their parents. Multivariate regression analysis identifies receipt of financial support for education and a home purchase as a positive contributor to net wealth and financial help for parents as a negative contributor to net wealth, disadvantaging Black college-educated households, who are less likely to receive and more likely to give financial support.

Longitudinal interview data collected in the Institute on Assets and Social Policy Leveraging Mobility study illustrate the mechanisms of family financial transfers and their relationship to wealth accumulation, contrasting the White and Black households' experiences. The discussion underscores the need to better understand intergenerational wealth and wealth sharing within families when studying wealth outcomes and highlights the role of family financial wealth transfers in creating opportunities for those who benefit the most—mostly White college-educated households. (JEL D14, D31, D63, D91, I24, J15)

Federal Reserve Bank of St. Louis Review, First Quarter 2017, 99(1), pp. 121-37.

http://dx.doi.org/10.20955/r.2017.121-137

Tatjana Meschede is senior scientist and research director, Joanna Taylor and Alexis Mann are research associates, and Thomas Shapiro is the Pokross Professor of Law and Social Policy and Director at the Institute on Assets and Social Policy, Heller School for Social Policy and Management, Brandeis University. This article was prepared for presentation at the symposium, "Does College Level the Playing Field? Racial and Ethnic Differences in Family Wealth Among College-Educated Families," sponsored by the Center for Household Financial Stability and the Research Division of the Federal Reserve Bank of St. Louis, May 25-26, 2016.

(0) 2017, Federal Reserve Bank of St. Louis. The views expressed in this article are those of the author(s) and do not necessarily reflect the views of the Federal Reserve System, the Board of Governors, or the regional Federal Reserve Banks. Articles may be reprinted, reproduced, published, distributed, displayed, and transmitted in their entirety if copyright notice, author name(s), and full citation are included. Abstracts, synopses, and other derivative works may be made only with prior written permission of the Federal Reserve Bank of St. Louis. 


\section{INTRODUCTION}

Understanding the relationship between educational achievement and wealth accumulation is more complex than the common-sense hypothesis might indicate. The hypothesis proposes that a college education is linked to higher incomes (Day and Newburger, 2002) and jobs with better benefits and stability (Chung, Davies, and Fitzgerald, 2010), suggesting college should be also linked to higher wealth accumulation trajectories over the life course. While there is little work to date investigating the relationship between education and wealth, recent work supports the hypothesis for White households but challenges it for Black households (Emmons and Noeth, 2015). The overarching goal of this paper is to better understand why the wealth of Black college graduates is not on the same trajectory as that of White college graduates. Specifically, we focus on family financial transfers to help better understand these divergent wealth trajectories.

Given that family wealth plays an antecedent role in educational choices and attainment that in turn impact wealth accumulation capacity, the racial wealth gap plays a significant role in the opportunities and barriers young people of color face. White students may capitalize on family resources to launch stable careers and continue wealth accumulation, while Black students may start out with fewer resources, resulting in lower long-term wealth returns. Further, recent research on the impact of the Great Recession (Emmons and Noeth, 2015) shows that educational attainment did not protect the wealth of Black families, as it did that of Whites, and is paradoxically associated with greater wealth declines than among less-educated Black families. Digging deeper into the wealth-education connection requires separating the issues of (i) how family wealth contributes to the likelihood of attending and completing college and (ii) how a college education impacts the ability to amass wealth. The cyclical nature of this process across generations raises issues of endogeneity, in which it is difficult to parse the impact of an individual's own education on wealth outcomes from the larger context of family wealth structures, all of which is situated within the racial context of the United States. Due to data limitations, our current analyses focus on Whites and Blacks and cannot be expanded to other population groups.

In particular, in this paper we address the following research questions based on data for the 1989-2013 period:

1. What are the wealth trends of White and Black college-educated households ${ }^{1}$ and how much do large financial gifts and/or inheritance contribute to racial wealth disparities?

2. What are the differences in family financial transfers-those given and received-for White and Black college graduates?

3. To what extent can family financial transfers, both into and out of the household, explain divergent wealth trajectories for White and Black college-educated households?

4. What are the processes and mechanisms by which family wealth transfers shape wealth trends among White and Black college-educated households? 


\section{LITERATURE REVIEW}

Now more than ever, a college education is considered a requirement to access stable and high-paying employment. Workers with a college degree are more likely to have benefits such as health insurance, paid leave, and retirement accounts and are less likely to experience unemployment (Chung et al., 2010). A Pew study (Pew Research Center, 2014) finds that among Millennials (ages 25 to 32 in 2013), those with a bachelor's degree had median earnings of $\$ 45,500$, more than $\$ 17,000$ more than their peers with only a high school diploma. Lifetime earnings for those with a college degree are expected to be about $\$ 1$ million more than for those with a high school diploma (Carnevale, Rose, and Cheah, 2011; Day and Newburger, 2002).

While the million-dollar return from college is true for all racial groups, total expected earnings for Blacks and Latinos are lower than for Whites and Asians at all education levels. Across the education spectrum, lifetime earnings of Latinos and Blacks are 34 percent and 23 percent lower, respectively, than those of Whites. Even among those with bachelor's and advanced degrees, lifetime earnings of Blacks and Latinos are 20 percent or more lower than those of similarly educated Whites - a gap of approximately $\$ 480,000$ (Carnevale et al., 2011).

Despite these differences, at least some post-secondary education is viewed as crucial for students of color to improve their socioeconomic standing. Over the past 30 years, college enrollment rates for Black and White students have converged ( 65 percent vs. 70 percent in 2013; Casselman, 2014); however, six-year completion rates have not (40 percent vs. 62 percent), leaving many young Blacks with student debt but no degree. In part because of this, wealth disparities begin to appear early in adulthood: In a recent analysis of young people with some post-secondary education, Whites report $\$ 17,000$ more in net wealth at age 25 than Blacks the same age (Addo, Houle, and Simon, 2016).

Family wealth is an important predictor of both college attendance and college completion. Family income is the most widely studied predictor of college attainment and strongly predicts college completion: A student from a family in the top income quartile is eight times more likely to complete college than a student from a family in the bottom quartile, 77 percent versus 9 percent (Pew Research Center, 2015). However, recent studies have argued that wealth is a stronger measure of resources available to pay for college, in part because of how wealth differences help explain educational attainment by race (Charles, Roscigno, and Torres, 2007). The racial wealth gap has been linked to many markers of household well-being and has grown in recent years (Shapiro, Meschede, and Osoro, 2013). After the Great Recession, the median Black family held only 1/20th the wealth of the median White family (Taylor et al., 2011). With the wealth of most families concentrated in their homes, students whose families experienced an increase in housing wealth just before reaching college age are more likely to enroll in college, attend higher-quality universities, and complete college, particularly students from lowincome families (Lovenheim, 2011). Black families have lower homeownership rates (Callis and Kresin, 2016), lower average home values (Shapiro et al., 2013), and were hit harder by the immediate and long-term impacts of the Great Recession (Shapiro et al., 2013), making it harder for them to use housing wealth to support higher education.

Some (e.g., Loury, 1985) have proposed that lower Black educational attainment is due to lower family investment in their children's education. In terms of nonmonetary invest- 


\section{Meschede, Taylor, Mann, Shapiro}

ments, such as day-to-day interactions promoting education and opportunities to build cultural capital, this is untrue: After controlling for household type and socioeconomic status, families of color are more likely to make significant nonmonetary investments in their children's future education (Charles et al., 2007). Instead, the overall investment gap is due to very different household composition and resource availability between White and Black households.

Very large and growing racial wealth disparities make Black households less likely to make monetary investments in their children's education. In fact, a recent study found that White students report an average of $\$ 12,000$ in financial assistance from parents, while Black students report an average of only $\$ 4,000$ (Addo et al., 2016), likely a result of differences in available resources. However, another recent study (Nam et al., 2015, p. 10) notes that "Black parents who help finance their children's education do so with far lower levels of income and wealth than White parents who choose not to do so," indicating a strong commitment to education among Black families. Moreover, the authors find that parental financial support for education eliminates the college completion gap. Without financial support, only 11.2 percent of Black children complete college, compared with nearly 25 percent of White children. With financial support, however, nearly 66 percent of Black children complete college, an insignificant difference from the 68 percent of White children who do so (Nam et al., 2015).

With or without financial support from parents, most students today expect to finance at least part of their education through student loans, which in turn impacts their wealth accumulation trajectories. In 2008, 66 percent of students receiving bachelor's degrees carried debt into their post-college lives, averaging nearly $\$ 25,000$ each (Hiltonsmith, 2013). In loans, too, Black and White students were unequal. While 65 percent of White students carried student loans, 80 percent of Black students did and averaged about $\$ 4,000$ more debt than their White counterparts (Hiltonsmith, 2013). Jackson and Reynolds (2013) argue that Black parents, even wealthy ones, may have less liquid or otherwise fungible assets that make it difficult to protect young people from high student loan burdens. In addition, Black students are more likely to leave college with debt but without a degree, which greatly increases the likelihood of defaulting and damaging their credit. While loans increase young Blacks' access to college, Jackson and Reynolds (2013) suggest that the debt may not always be worth the risk. Indeed, student loans are a drag on wealth accumulation after college. Hiltonsmith (2013) shows that for a dual-college household with average loan burdens, student debt will reduce the family's wealth by over $\$ 200,000$ at 63 years of age. Since Black college graduates tend to have higher debt burdens and lower incomes, it is likely that this wealth drag is even greater for them, leading to lower wealth accumulation and less ability to support their own children's educational aspirations, contributing to the "sedimentation of inequality" (Shapiro and Oliver, 2006, p. 52).

Beyond college support, family financial transfers are an important ongoing source of wealth accumulation capacity. They may smooth the transition into young adulthood through rent support or help with a down payment on a home and also provide later transfers through bequests or even assistance to grandchildren. Studies have shown that financial gifts from parents to adult children comprise at least 20 percent of wealth, and inheritances account for up to 50 percent of total wealth in the United States (Gale and Scholz, 1994). And White house- 
holds are more likely to receive inheritances and financial gifts than their counterparts of color (Jayakody, 1998) and in larger amounts (Shapiro et al., 2013). Such transfers are therefore an important addition to the picture of how wealth and education interact across time. Because Black families are at a constant disadvantage across the life course in terms of wealth available for transfer, young Black college graduates are much more likely than their White counterparts to start off with debt or no wealth and continue to receive less financial support from family. A recent study (Pfeffer and Killewald, 2015) looks at multi-generational transfers of wealth and finds that education transfers mediate a great deal of the wealth transfers overall across three generations but also that Black families are far more likely to be downwardly than upwardly mobile. However, this study's ability to capture the true importance of grandparent-grandchild transfers may be significantly limited by the available data, overemphasizing the role of education in mediating wealth transfers. Thus, even though education may be an important pathway to wealth for non-Whites, the accumulated disadvantage of wealth disparities continues to hinder their future wealth accumulation.

Education itself does not equalize wealth accumulation opportunities among Black and White families. Early career opportunities for Blacks continue to be hampered by discrimination in both hiring and salary (Gaddis, 2014), impacting long-term wealth potential. Hamilton et al. (2015) point out that Black households with college-educated heads have 33 percent less wealth than White households headed by high school dropouts. And while Black families with college degrees have significantly more wealth than those without degrees (approximately $\$ 23,400$ with a B.A. vs. only $\$ 3,200$ with a high school diploma), there is a nearly $\$ 160,000$ difference between the wealth of college-educated Black and White households (Hamilton et al., 2015). Brown (2016) examines wealth trajectories as people age and finds that even after controlling for education, health, and behavioral factors, Black families headed by a 51 year old have only 11 percent of the wealth of their White counterparts and that the wealth gap continues to grow through age 66.

Despite the importance of education in job and earnings prospects, college attainment does not protect Black wealth. An analysis of Survey of Consumer Finances (SCF) data (Emmons and Noeth, 2015) found that college-educated Black families lost a larger percentage of both net wealth and real income as a result of the Great Recession (between 2007 and 2013) than White families and even less-educated Black families. Specifically, during the Great Recession, college-educated White families lost only 16 percent of their net wealth compared with 32 percent for White families without a college degree, while college-educated Black families lost nearly 60 percent of their net wealth compared with 37 percent for less-educated Black families. One possible explanation for this non-intuitive finding lies in studies showing that extended kin networks are important avenues for wealth transmission in the Black community; that is, Blacks who have "made it" into the middle class are still tied to family members struggling to get by and provide loans and other monetary support to them (Chiteji and Hamilton, 2005). O'Brien (2012) tested this hypothesis and found that middle- class Blacks are indeed more likely to provide informal financial assistance to extended networks, depleting their own wealth accumulation capacity through "negative social capital." Thus, it is possible that college-educated Blacks transferred a significant amount of wealth to family networks 


\section{Meschede, Taylor, Mann, Shapiro}

during the Great Recession to prevent foreclosure or other negative outcomes, explaining the greater wealth declines for more-educated Black households.

In conclusion, the literature, then, points to the importance of wealth in accessing and completing higher education and the structural difficulty Black families face in accumulating wealth despite a college degree. This paper adds to the literature by exploring the racial wealth gap between White and Black college-educated families over 1989 to 2013, examining the impact of family financial transfers in accumulating wealth over multiple generations.

\section{METHODS}

The aims of this research are manifold. We begin with quantitative analyses conducted in three steps. First, we test Emmons and Noeth's (2015) results on disparate wealth accumulation outcomes for White and Black college-educated households but use a different national data set. Second, we examine the impact of large family financial gifts and/or inheritances on racial wealth disparities. Lastly, we examine the impact of targeted family financial transfers, such as for education and/or a home purchase or monetary support of parents, on wealth accumulation and racial wealth disparities. The qualitative data highlight the processes that help explain the quantitative results.

\section{Data Sets}

This mixed-method study uses two complementary datasets that track wealth and family financial transfers of White and Black households over time: the Panel Study of Income Dynamics (PSID) and the Institute on Assets and Social Policy (IASP) Leveraging Mobility (LM) study. The PSID is a longitudinal dataset that has been tracking households and their descendants since 1968 and has widened its initial focus on income and employment to include wealth, health, expenditures, child development, and other data collection modules over the years. The main interview of the PSID also collects information on family financial transfers in the form of large gifts and/or inheritances. The PSID initially oversampled lowerincome and Black populations but was refreshed in 1997, adding 511 immigrant families to the panel to keep up with demographic changes in the United States. Specifically, we analyze wealth trends and family financial transfers of college-educated White and Black household heads over 1989-2013 and the impact of family wealth transfers on household wealth in 2013. Variables used in this analysis include receipt of a large gift and/or inheritance, collected in the main PSID survey, and national family financial transfers data collected in the 2013 Family Roster and Transfers Module as part of the PSID. This newer module includes data on living parents and adult children (over 18 years of age) of respondents and their spouses/partners.

The LM study is a unique qualitative dataset based on in-depth interviews conducted at two points in time, in 1998 and between 2010 and 2012. It offers a rare look at the financial lives of White and Black families and the decisions and trade-offs between financial security and opportunities made during a decade of particular economic volatility. In 1998, the original sample of 180 families was purposefully selected to represent even proportions of White and Black families and working class and middle-class families. At baseline, these families 
had children between ages 3 and 10. The second wave of interviews included 137 of the families, with their children at the end of high school or beyond and the parents in the latter half of their working lives, between ages 40 and 60 . The racial breakdown remains the same in the follow-up interviews as in the baseline. Aside from a few moves to other locations, the LM families continued to reside in three cities: one city on the East Coast, one city on the West Coast, and one city in the Midwest. The interviews cover a wide range of data, including information about the children's educational histories and trajectories, parents' work histories, family income and expenditures, family wealth and debt, family financial and non-financial assistance, the community or communities where they resided previously and at the time, and reflections about their economic security and decisions made related to assets. Using case studies of White and Black college-educated households, this paper illustrates (i) how family financial transfers operate to help families increase their wealth and provide financial support during economic crises, (ii) how the lack of such transfers may put families on a downward economic path, and (iii) how the results differ by race.

\section{RESULTS}

To address the three quantitative research aims, corresponding analyses were conducted as follows. First, we compute the median wealth of college-educated households for each year the PSID main interview provides wealth data, starting in 1989, which reflects the Emmons and Noeth (2015) study period, 1989 to 2013. For the same time period, we sum all reported receipts of large financial gifts and/or inheritances and test the extent of their contribution to racial wealth disparities in 2013. We then turn to the PSID 2013 Rosters and Transfers Module and explore differences among targeted financial transfers between parents and their adult children by race. Finally, we conduct multivariate regression analyses to test the impact of these transfers on wealth. A college-educated household is defined, according to PSID terminology, as either the head or wife having a college degree or higher. The definition of race is based on the head of household. All results are weighted.

All LM study interview data are coded using qualitative analytic software (NVivo), applying a grounded theory analytic approach to determine key processes and mechanisms of family wealth transfers that explain the quantitative trends. Case studies of typical LM families illustrate these processes.

\section{Black and White Wealth Trends Over 24 Years}

As Emmons and Noeth (2015) discovered by analyzing SCF data, we find by analyzing the PSID: The wealth trends of college-educated White and Black households contribute to the overall widening of racial wealth disparities. Over the 1989 to 2013 period, the median net wealth of White college-educated households (including home equity) increased by $\$ 31,343$ on average, whereas their Black counterparts lost $\$ 19,816$ on average (Figure 1). In fact, the median net wealth of college-educated Black households peaked in 1994 at $\$ 71,717$ and has decreased since. The absolute racial wealth gap between White and Black households increased from roughly $\$ 142,000$ to $\$ 193,000$, while the ratio of White to Black wealth tripled over the study period. 


\section{Figure 1}

\section{Median Net Wealth (Including Home Equity) of Non-Hispanic College-Educated White and Black Households, 1989-2013}

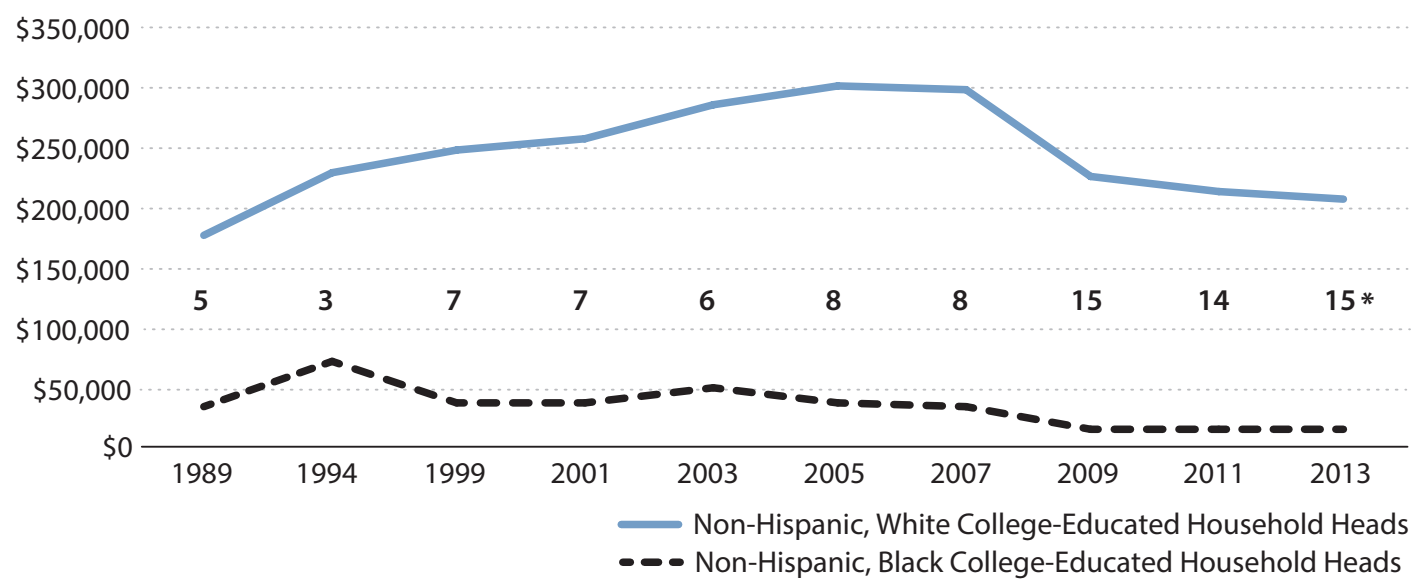

NOTE: *White/Black wealth ratios.

SOURCE: PSID and authors' calculations.

\section{Figure 2}

\section{Median Net Wealth (Excluding Home Equity) of Non-Hispanic College-Educated White and Black Households, 1989-2013}

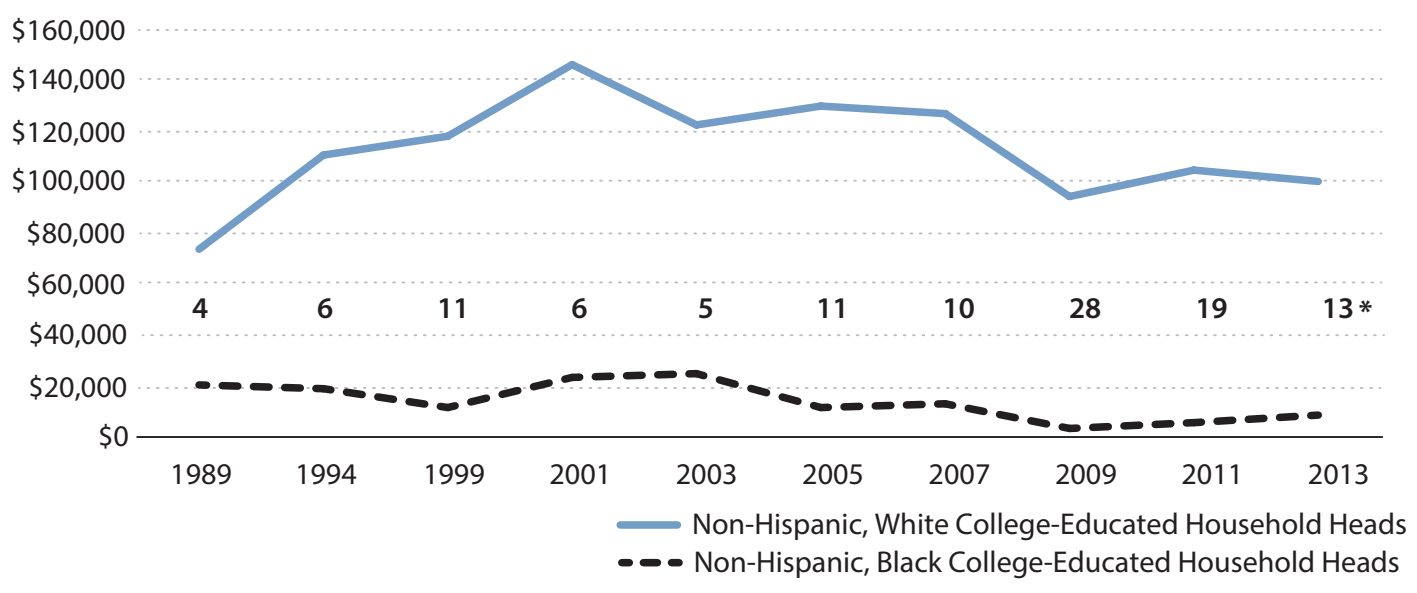

NOTE: *White/Black wealth ratios.

SOURCE: PSID and authors' calculations. 
It is worth noting, however, that unlike the findings from the SCF (Emmons and Noeth, 2015), the decline in White wealth continued after the Great Recession. The net wealth of college-educated White households was lower in 2013 than in 1994, mostly due to the large drop after 2007 and no recovery since (see Figure 1). Yet, because the loss of net wealth among college-educated Black households began before 2007 and has steadily declined since, the ratio of White to Black wealth is the highest in the years following the Great Recession, indicating growing racial wealth disparities since that economic downturn.

Trends of racial wealth disparities are overall similar for wealth estimates that do not include home equity, the largest component of wealth for most U.S. households (Figure 2). However, the highest reported wealth holdings that exclude home equity are reported for 2001 for White and 2003 for Black college-educated households and have been on the decline since. Even with this difference in overall trends, White college-educated households have increased wealth, while Black college-educated households have lost wealth over the entire study period.

\section{Impact of Large Financial Gifts and/or Inheritances Over Time}

The next step in the analysis focuses on what is typically viewed as financial transfers between generations: large financial gifts and inheritances. The PSID survey collected these data at each wave and defines such transfers as $\$ 10,000$ or more. We sum these transfers over the study period and adjust for inflation to determine their contribution to wealth in 2013. Among college-educated households, very few Black households (9 percent) received such a large financial gift, compared with close to one-third of college-educated White households (32 percent). Consistent with past research, not only do very few Black households receive such large family financial transfers, but when they do they are significantly smaller. White college-educated families received $\$ 55,419$ at the median and $\$ 235,353$ at the mean, while their Black counterparts received $\$ 36,260$ and $\$ 65,755$, respectively.

After deducting the sum of all large financial transfers from 2013 household net wealth (including home equity), median net wealth estimates dropped by close to $\$ 40,000$ on average for White college-educated households but remained unchanged for Black households, reducing the racial wealth gap by 20 percent. This estimate, however, is low because it does not account for wealth-generating activities resulting from financial transfers or the debt and interest payments avoided.

\section{Targeted Family Financial Transfers and Wealth of College-Educated Households}

We now turn to financial transfers mostly given for a specific purpose and not restricted to large amounts. The new PSID 2013 module on family transfers allows us to study financial transfers across different purposes and different generations, including the inflow and outflow of wealth transfers between two generations and among member families. In particular, these data include information on financial support from parents for education, a home purchase, or other unspecified financial support over the life course; on financial support provided by parents to either the head or the wife in 2012 specifically; and the amount of the transfer in 2012. In addition, households also report financial transfers and amounts in 2012 to their 


\section{Table 1}

\section{Financial Transfers In and Out of Households by Race}

\begin{tabular}{|c|c|c|}
\hline & $\begin{array}{c}\text { White } \\
(N=2,159)\end{array}$ & $\begin{array}{c}\text { Black } \\
(N=638)\end{array}$ \\
\hline \multicolumn{3}{|l|}{ Transfers into households } \\
\hline Whether received \$ from parents in 2012 & $33 \% *$ & $24 \%$ \\
\hline Total \$ from parent to household (mean) & $\$ 4,446^{* * *}$ & $\$ 1,313$ \\
\hline Total \$ from parent to household (median) & $\$ 1,000$ & $\$ 500$ \\
\hline \multicolumn{3}{|l|}{ Since turning $18 \ldots$} \\
\hline Whether parent helped pay school of head/wife & $60 \% * * *$ & $37 \%$ \\
\hline Whether parent helped with home purchase & $17 \% * * *$ & $5 \%$ \\
\hline Whether other financial parental help & $28 \%$ & $29 \%$ \\
\hline \multicolumn{3}{|l|}{ Transfers out of households } \\
\hline Whether household gave \$ to parents in 2012 & $16 \% * * *$ & $45 \%$ \\
\hline Total amount to parents (mean) & $\$ 1,776^{*}$ & $\$ 1,193$ \\
\hline Whether household gave $\$$ to adult children in 2012 & $63 \%$ & $49 \%$ \\
\hline Total amount to adult children (mean) & $\$ 7,955^{* * *}$ & $\$ 3,095$ \\
\hline \multicolumn{3}{|l|}{ Since child turned $18 \ldots$} \\
\hline Whether household helped pay for school for child & $64 \% * * *$ & $34 \%$ \\
\hline Total amount paid for school for child (mean) & $\$ 73,378^{* * *}$ & $\$ 16,182$ \\
\hline Whether household helped pay for home purchase for child & $12 \% * * * \dagger$ & $4 \%$ \\
\hline Total amount paid for home for adult child (mean) & $\$ 66,735$ & $\$ 6,444$ \\
\hline Whether household gave other financial help to adult child & $31 \%$ & $26 \%$ \\
\hline Total amount for other financial help for adult child (mean) & $\$ 22,575^{*}$ & $\$ 9,664$ \\
\hline \multicolumn{3}{|c|}{$\begin{array}{l}\text { NOTE: * } p=<0.05 ;{ }^{* * *} p<0.001 . p \text {-Values comparing monetary amounts are based on two-way t-test estimates. The } \\
\text { sample is restricted to college-educated households, defined by either the PSID head's or wife's attainment of a bach- } \\
\text { elor's degree or higher. † Surprised by the low rates of financial support for home purchases, we checked the Federal } \\
\text { Reserve Board Survey of Household Economics and Decisionmaking data, which confirm overall low rates of financial } \\
\text { support from parents or other family when purchasing a home. }\end{array}$} \\
\hline
\end{tabular}

parents and/or adult children. Lastly, information on payments for adult children's education, home purchase, or other financial needs since these children turned 18 is provided. Table 1 compares the results for White and Black college-educated households and finds statistically significant differences in financial transfers into and out of these households.

White college-educated household were significantly more likely to report having received financial support from their parents in 2012. The average transfer received was three times higher at the mean and twice as high at the median than that reported by Black collegeeducated households. Further, these White households were close to twice as likely to have received financial assistance from their parents for education and more than three times as likely for purchasing a home. White college-educated parents were also significantly more likely to financially support adult children's education and home purchase. Not only were these white parents more likely to provide financial assistance to their young adult children, they also were able to give significantly higher amounts. Most notable is the difference for 
college payments. These White parents contributed close to $\$ 73,500$, on average, to their children's education, compared with just over $\$ 16,000$ that Black college-educated parents were able to provide. While such financial gaps may be filled by scholarships, some will also require student loans, launching students on very different economic trajectories into adulthood.

The trends of providing family financial support largely reverse on payments to parents. Proportionately, close to three times as many college-educated Black households than White college-educated houses provided financial support to their parents. Those White households that did support their parents, however, provided more money on average than the Black households did: $\$ 1,800$ versus $\$ 1,200$.

In sum, White college-educated households are significantly more likely to receive financial transfers from their parents, whereas Black college-educated households are significantly more likely to provide financial support to their parents. The significant and substantial differences in intergenerational financial transfers have long-lasting impacts, both for the givers and the receivers. How much these transfers impact household wealth holdings is addressed in the next section.

\section{Multivariate Regression Analysis Linking Financial Transfers and Net Wealth}

The final step in the quantitative analysis uses multivariate regression to test the correlation between financial transfers and household net wealth of college-educated households. In our model, wealth is transformed using the inverse hyperbolic sine function ${ }^{2}$ to correct for the extreme skewness of the wealth distribution. The variables in the regression model include demographic controls (age, marital status), race, and financial transfers received and financial transfers provided by the household. We estimate two models, adding race and transfer interaction terms to the second model (Table 2).

The findings reiterate the positive relationships of age and marital status with higher wealth holdings, and the dramatic decrease of wealth for Black-headed households (by roughly 450 percent in both models).

In Model 1, having received financial support for education and/or a home purchase contributes significantly to higher net wealth, while having received a financial transfer for another unspecified purpose significantly reduces net wealth. Financial transfers to parents (much more common among Black college-educated households) significantly decrease household net wealth by more than 25 percent. Further, providing financial help to an adult child for unspecified purposes other than education or a home purchase is significantly associated with higher wealth holdings. Having provided any financial support for an adult child in 2012 or for their education or home purchase is not significantly related to net wealth.

Interaction terms generated for all transfer variables identified to have significant differences by race are added to the regression in Model 2 to further test the role of race in disparate wealth outcomes. However, the interaction terms add little explanatory power to the model. Overall, the results indicate no differences in results compared with Model 1 except for financially supporting parents, which no longer is significant in the interaction model. Only one of the race interaction terms (Any financial help from parents in 2012) significantly predicts less net wealth in 2013. 


\section{Table 2}

Effects of Family Financial Transfers on Net Wealth (Inverse Hyperbolic Sine Transformed), Estimated by Linear Regression (Ordinary Least Squares)

\begin{tabular}{|c|c|c|}
\hline & $\begin{array}{c}\text { Model } 1 \\
\text { coefficient }\end{array}$ & $\begin{array}{c}\text { Model } 2 \\
\text { coefficient }\end{array}$ \\
\hline \multicolumn{3}{|l|}{ Demographics } \\
\hline Age (head) in 2013 & $0.51^{* * *}$ & $0.49 * * *$ \\
\hline Age (head) in 2013, squared & $-0.003 * * *$ & $-0.003^{* * *}$ \\
\hline Married in 2013 & $2.76^{* * * *}$ & $2.82^{* * *}$ \\
\hline \multicolumn{3}{|l|}{ Race } \\
\hline Black (head) & $-4.64^{* * *}$ & $-4.39 * * *$ \\
\hline \multicolumn{3}{|l|}{ Transfers into households } \\
\hline Any help from parents in 2012 & 0.12 & 0.03 \\
\hline Parents help school & $1.07^{* *}$ & $1.35^{* *}$ \\
\hline Parents help home & $1.69 * *$ & $1.77^{* *}$ \\
\hline Parent help other & $-1.90^{* * *}$ & $-1.83^{* * *}$ \\
\hline \multicolumn{3}{|l|}{ Transfers out of households } \\
\hline Help of parents in 2012 & $-0.26^{*}$ & -0.14 \\
\hline Help child in 2012 , any & -0.16 & -0.15 \\
\hline Help child school & -0.19 & -0.20 \\
\hline Help child home & -0.12 & -0.18 \\
\hline Help child other & $0.34^{*}$ & $0.33^{*}$ \\
\hline \multicolumn{3}{|l|}{ Interaction terms (race) } \\
\hline Any help from parents $2012 \times$ Race & & $-0.41^{*}$ \\
\hline Parents help school $\times$ Race & & 0.39 \\
\hline Parents help home $\times$ Race & & -0.17 \\
\hline Help of parents $2012 \times$ Race & & 0.33 \\
\hline Help child school $\times$ Race & & -1.37 \\
\hline Help child home $\times$ Race & & -1.31 \\
\hline Adj. $R^{2}$ & 0.24 & 0.25 \\
\hline$N$ & 2,797 & 2,797 \\
\hline
\end{tabular}

Note: ${ }^{*} p=<0.05 ;{ }^{* *} p<0.01$; and ${ }^{* * *} p<0.001$. The sample is restricted to college-educated households, defined by either the PSID head's or wife's attainment of a bachelor's degree or higher.

Somewhat puzzling are the findings with respect to non-specified financial support other than for education or a home purchase. Receiving financial support from parents for other expenses is significantly associated with lower net wealth. Based on findings from analysis of the LM study data, we are confident these financial contributions are for emergency expenses of households in an economic crisis. Because these financial transfers are most likely small in nature and needed for immediate use (e.g., car repairs or a broken appliance), they do not contribute to wealth accumulation. In turn, parents who financially support their adult children 
for other expenses may have high wealth, so these contributions would not detract from their already high wealth holdings.

\section{Real Families, Real Life Experiences}

We now turn to individual families to help illustrate the mechanisms shaping these larger trends. Examining how and why the process unfolds leads to a more compelling understanding of the life situations of White and Black college-educated families and the role family wealth plays. Overall, the trends in family financial transfers of LM families reflects that of the national PSID sample, with fewer Black families receiving family financial assistance over the study period. Below we illustrate how such financial transfers impact wealth trajectories for specific college-educated families in our sample.

Over the years of the LM study, it was not uncommon for White households to receive financial support from their families, mostly their parents. Such support has helped these families access key investment or "head start" resources such as a contribution toward the purchase of a home, a debt-free college education, or support to help bridge periods of economic vulnerability. One such family is the Scullys, a White, middle-class family raising two children on the East Coast. While the family's household income has declined since 1998, they have gained economic mobility through increasing their home equity and inherited assets. Marvin and Jackie purchased a fixer-upper home in their ideal neighborhood in 1999. With Marvin working in construction, he was able to renovate it himself. They paid $\$ 225,000$ for the house and made a down payment of $\$ 25,000$ with the help of a substantial contribution of $\$ 20,000$ from their parents. The couple would not have been able to afford the house without family help. The home appreciated in value quickly, and Jackie believed they had over $\$ 300,000$ in equity in 2010 . While the couple loved the community's diversity and green space, they weren't thrilled with the quality of the local public school and decided to send their daughter to private school. Tuition was $\$ 10,000$ a year, and they covered the cost through a private loan from a local credit union and paid that loan off with a home refinance.

In 2007, Marvin inherited $\$ 100,000$ cash from his mother (and another $\$ 100,000$ in a tax-restricted annuity). He put this inheritance toward the house, which reduced the principal to $\$ 200,000$ and also dropped their mortgage interest rate. Receiving most of their down payment and a substantial inheritance from their parents set this family on a very different path toward amassing wealth from that of our next family, the Barzaks, a Black middle-class couple with two daughters.

Steve and Christa Barzak depend solely on the stability of their income and the money they have set aside in their $401(\mathrm{k})$ to cover daily costs and long-term investments. With no help from family, in 1997, the Barzaks used a large chuck of their retirement funds and savings for a down payment on a condo. With two full-time jobs, investing in a home in a good school district felt like the next step for this young family. They pulled equity from the condo for renovations, and they both felt confident this investment would be a stepping stone if they wanted to purchase a larger house as their kids grew. But over the next 10 years the house lost value, and the Barzaks could no longer cover their monthly mortgage payments as their household income declined. 
At the height of the Great Recession, Steve was laid off from his management job. Unable to find a comparable position, he took a range of part-time hourly jobs with no benefits. By 2009 Steve lost his part-time construction job and Christa was unable to find work. Their income had dropped from $\$ 84,000$ in 1998 to $\$ 20,000$. Having exhausted their own savings and retirement funds and without any extended family support to help them through this rough financial period, the family lost their largest asset investment to foreclosure and had to pull their daughters from private school.

By 2010 neither Steve nor Christa had a strong sense of economic security. The family had experienced severe downward income and wealth mobility, and Steve had fallen from top management positions in telecommunications and construction to cobbling together remodeling side jobs. Neither Christa nor Steve had expected this outcome:

Steve: "2009 was the least financially successful year of our marriage...We're one step above poverty. But [we're] one step above."

Christa: "When you grow up a certain way and you go to college, never in your wildest dreams do you ever think or consider public assistance."

The Coates family, like the majority of Black families in the LM study, increased their net wealth solely through their careers and increasing home values. In 1998, they were living in Los Angeles. Facing limited opportunities for career advancement and displeased with the local public school options for their children, Bianca and her husband decided to move to a place where they could afford to live in a good school district. Balancing career and educational opportunities, their search brought the family to Atlanta, Georgia. They had accumulated considerable equity in their home in California, and they sold it at the peak of the housing bubble. Such a move enabled them to buy a nice home in Atlanta in a gated community.

This relocation also allowed Bianca to capitalize on the Master's degree she had just completed, securing an upper management position at a local hospital, which significantly increased the family's annual income. Her husband, a nurse, was able to quickly find work. For the Coates family, steady employment with robust benefits including retirement funds, medical insurance, and a pension has meant steady increases to both household income and wealth.

\section{DISCUSSION}

From what we know about the lifetime earnings advantage of a college education, we would expect wealth growth for college-educated households and perhaps a narrowing of the racial wealth gap. However, the analysis in this paper confirms findings of prior research, showing that the typical Black college-educated household does not have the same opportunities to add to their family balance sheet as their White counterparts, who report large wealth gains at least up to the Great Recession. To better understand the role of family wealth in these trends, we analyzed the impacts of inheritance and targeted financial transfers in explaining these seemingly puzzling trends, thereby broadening our understanding of inherited wealth as well as wealth invested in the next generation. 
New data collected as part of the PSID allow us to quantitatively analyze financial transfers by type of transfer, such as for school support or a home purchase, and relate these transfers to household wealth and racial wealth disparities among college-educated households. These data confirm prior research on the role of parental wealth in the transmission of lasting economic advantage: Less-wealthy parents, mostly Blacks, are less able to financially help their adult children, making it more difficult for the next generation to accumulate wealth. In addition, Black college-educated households are far more likely than their White counterparts to give financial support to their parents. These parents may have entered the workforce at a time when their only employment provided no pension or retirement savings benefits, or even Social Security. In contrast, parents of White college-educated households have mostly benefited from employment-related retirement benefits. Thus, the pattern among White and Black college-educated households is the opposite: Young college-educated White households are more likely to receive financial support from parents and at considerably higher levels.

With the need to simultaneously support parents and children, educational and economic achievements of Black professionals become thinly stretched. As one high-earning Black professional in the IASP LM study shares,

It's really odd...What's really bizarre is that people think that you make all this money. When you have aging parents who you're helping, and you've got a daughter who is going through what she is going through [Tourette's syndrome], and another daughter in college, it gets spread out so thin.

The data presented here remind us that inheritance involves much more than the common understanding of large bequests at the death of parents or grandparents. The traditional distinction wonders about in vivo transfers, but with increasingly better and deeper data, the time has come to move toward a more robust and analytically accurate notion of inheritance that includes as many intergenerational human and financial transfers as possible. Quite specifically, this picture must include financial assistance with a home purchase; support for higher education; large gifts to young families; financial starter packages as weddings gifts; the funding of private schooling, test prep, and summer camps; and so on.

While the understanding of the contextual family situation of college-educated Black households has not, as yet, been incorporated in analyses that focus primarily on the household's immediate bottom line, it may lead to a false impression that the financial behavior of Black households needs improvement more in line with classical economics. As noted, Black college graduates are far more likely to come from less-educated families who earned considerably less during their lifetimes and hence are in more need of financial help from their grown children. The adult children most likely to help are those who have attained educational and financial success-most likely college graduates. As the data show, Black college graduates are more likely than White college graduates to financially help their parents (and others), with lasting implications for not only their own net wealth but also that of their children.

We are not judging financial choices but simply raising the critical issue that wealth is not a goal in itself but a means to economic security, protection, lifestyle, life chances, social mobility, and aspirations. Limiting our examination to gains in net wealth at Time 2 compared with Time 1 misses the important discussion of how families utilize wealth. Further, it engen- 


\section{Meschede, Taylor, Mann, Shapiro}

ders an explanatory search for behavioral and character deficits, turning analytic gazes and narratives away from contextual family circumstances, institutions, policy, and historical legacy. We suggest that the outflow of resources to needy parents and others is an important utilization of wealth for Blacks that differs significantly from the situation of Whites. Our understanding of family wealth needs to move beyond the proverbial bottom line to utilization. What is "better"-money in stocks and bonds and savings accounts, or helping to send nieces to college and supporting older parents with living and health situations? Wealth is a means, not a goal.

We eagerly accepted the challenge of this paper to better comprehend why Black college graduates apparently lose wealth compared with their White counterparts. We end by underscoring that the economic situation of Black college graduates is not comparable to that of White graduates because of contextual family circumstances, student debt loads, receiving and giving financial support patterns, and histories of family wealth.

\section{NOTES}

1 In this paper we use the terms "college educated" and "college graduates" interchangeably. Both refer to our sample of households in which either spouse or both have attained a college degree.

2 The inverse hyperbolic sine transformation is defined as $\log \left(y_{i}+\left(y_{i} 2+1\right) 1 / 2\right)$ and is approximately equal to $\log \left(2 y_{i}\right)$ or $\log (2)+\log \left(y_{i}\right)$, except for very small values of $y$. The interpretation of the generated coefficients is equal to the interpretation of a standard logarithmic dependent variable.

\section{REFERENCES}

Addo, F.R.; Houle, J.N., and Simon, D. "Young, Black, and (Still) in the Red: Parental Wealth, Race, and Student Loan Debt." Race and Social Problems, 2016, 8(1), pp. 64-76; https://doi.org/10.1007/s12552-016-9162-0.

Brown, T.H. "Diverging Fortunes: Racial/Ethnic Inequality in Wealth Trajectories in Middle and Late Life." Race and Social Problems, 2016, 8(1), pp. 29-41; https://doi.org/10.1007/s12552-016-9160-2.

Callis, R.R. and Kresin, M. Residential Vacancies and Homeownership in the Fourth Quarter 2015. Washington, DC: U.S. Census Bureau, 2016.

Carnevale, A.P.; Rose, S.J. and Cheah, B. "The College Payoff: Education, Occupations, Lifetime Earnings." Georgetown University Center on Education and the Workforce, 2011.

Casselman, B. “Race Gap Narrows in College Enrollment, But Not in Graduation." FiveThirtyEight.com, 2014.

Charles, C.Z.; Roscigno, V.J. and Torres, K.C. "Racial Inequality and College Attendance: The Mediating Role of Parental Investments." Social Science Research, 2007, 36(1), pp. 329-352; https://doi.org/10.1016/j.ssresearch.2006.02.004.

Chiteji, N. and Hamilton, D. "Family Matters: Kin Networks and Asset Accumulation," in Sherraden, M., ed., Inclusion In The American Dream: Assets, Poverty, And Public Policy. Oxford University Press, 2005, pp. 87-111.

Chung, W.; Davies, P. and Fitzgerald, T.J. "Degrees of Job Security." Federal Reserve Bank of Minneapoli Region, December 2010, pp. 4-13.

Day, J.C. and Newburger, E.C. "The Big Payoff: Educational Attainment and Synthetic Estimates of Work-Life Earnings." Current Populations Reports P23-210, U.S. Department of Commerce, 2002.

Emmons, W.R. and Noeth, B.J. "Why Didn't Higher Education Protect Hispanic and Black Wealth?" Federal Reserve Bank of St. Louis Center for Household Financial Stability In the Balance, 2015, Issue 12. 
Gaddis, S.M. "Discrimination in the Credential Society: An Audit Study of Race and College Selectivity in the Labor Market." University of North Carolina Chapel Hill Social Forces, 2014, pp. 1-29.

Gale, W.G. and Scholz, J.K. "Intergenerational Transfers and the Accumulation of Wealth." Journal of Economic Perspectives, 1994, 8(4), pp. 145-60; https://doi.org/10.1257/jep.8.4.145.

Hamilton, D.; Darity Jr, W.; Price, A. E.; Sridharan, V. and Tippett, R. “Umbrellas Don't Make It Rain: Why Studying and Working Hard Isn't Enough for Black Americans." Unpublished manuscript, The New School, 2015.

Hiltonsmith, R. At What Cost: How Student Debt Reduces Lifetime Wealth. Vol. 3. Demos, 2013.

Jackson, B.A. and Reynolds, J.R. "The Price of Opportunity: Race, Student Loan Debt, and College Achievement." Sociological Inquiry, 2013, 83(3), pp. 335-68; https://doi.org/10.1111/soin.12012.

Jayakody, R. "Race Differences in Intergenerational Financial Assistance, the Needs of Children, and the Resources of Parents." Journal of Family Issues, 1998, 19(5), pp. 508-33; https://doi.org/10.1177/019251398019005002.

Loury, G.C. "The Moral Quandary of the Black Community." Public Interest, 1985, Issue 79.

Lovenheim, M.F. "The Effect of Liquid Housing Wealth on College Enrollment." Journal of Labor Economics, 2011, 29(4), pp. 741-71; https://doi.org/10.1086/660775.

Nam, J.; Hamilton, D.; Darity Jr, W. and Price, A. Bootstraps Are for Black Kids: Race, Wealth, and the Impact of Intergenerational Transfers on Adult Outcomes. Oakland, CA: Insight Center for Community Economic Development, 2015.

O’Brien, R.L. “Depleting Capital? Race, Wealth and Informal Financial Assistance." Social Forces, 2012, 91(2), pp. 375-96; https://doi.org/10.1093/sf/sos132.

Pew Research Center. “The Rising Cost of Not Going to College." 2014.

Pfeffer, F.T. and Killewald, A. "How Rigid Is the Wealth Structure? Intergenerational Correlations of Family Wealth." Population Studies Center, University of Michigan, 2015.

Shapiro, T.M.; Meschede, T. and Osoro, S. "The Roots of the Widening Racial Wealth Gap: Explaining the BlackWhite Economic Divide." Institute on Assets and Social Policy, 2013.

Shapiro, T.M., and Oliver, M.L. Black Wealth/White Wealth: A New Perspective on Racial Inequality. New York, NY: Routledge, 2006.

Taylor, P.; Kochhar, R.; Fry, R.; Velasco, G. and Motel, S. Wealth Gaps Rise to Record Highs Between Whites, Blacks and Hispanics. Washington, DC: Pew Research Center, 2011. 
